\title{
Description's Repertoire: the Journals of R. F. Langley
}

\begin{abstract}
This essay offers an extended reading of the poet R. F. Langley's Journals, a volume gradually coming to be recognised as a major work in an English tradition of descriptive writing on art, architecture and natural history. Langley's descriptive practice has additional significance today as description experiences something of a revival, conceived both as a form of what we might now call creative-critical writing and within an academy concerned variously with the possibility of a so-called 'postcritical' attitude. Following a brief sketch of this contemporary scene, the essay identifies a Langleyan repertoire of description in a series of modest turns on the rhetorical mode of ekphrasis and on the discourse that has accompanied description through the ages.
\end{abstract}

The publication of R. F. Langley's Complete Poems in 2015 brought into the mainstream or thereabouts a small body of work long admired by a coterie of readers. Langley's Journals, the selection of his descriptive prose published in 2006, has benefited from increased interest in the poetry, but has also been developing a reputation of its own: 'equally [as] astonishing' as the poems, in Helen Mcdonald's judgement. ${ }^{1}$ The prose sits in a loosely constituted history of journal and essay writing that includes Dorothy Wordsworth, Ruskin, Hopkins and Adrian Stokes. ${ }^{2}$ The tradition in question is characterised by sustained passages of fine verbal description, whether minimalist or expansive, focusing most commonly on art, architecture, wildlife and natural history. ${ }^{3}$ Langley inflects this inheritance with his reading in

Notes

1 'Helen Mcdonald: the Six Books That Made Me', Guardian 28 January 2015, https://www.theguardian.com/books/2015/jan/28/helen-macdonald-h-is-for-hawkcosta-prize-six-nature-books (last accessed 14 August 2017).

${ }^{2}$ Langley began keeping a journal in 1969. Individual entries from it appeared in $P N$ Review from November 2002. Shearsman then published a volume of selected entries in 2006 and it is on this text that I concentrate here (R.F. Langley, Journals (Exeter: Shearsman, 2006); all further references to this edition). Posthumous publication of additional entries began in 2015, again in PN Review, transcribed by Jeremy NoelTod, editor of Langley's Collected Poems.

${ }^{3}$ On the Journals as standing in an English tradition of 'astute annotations of poetic perception', see Peter Larkin, ‘Being Seen for Seeing: A Tribute to R. F. Langley's 
phenomenology and psychoanalysis, each understood as a form of descriptive attending to experience; and yet one at least of the antecedents of the register in question is much older than these modern philosophies, namely the rhetorical exercise of ekphrasis, understood both according to the restricted modern usage as a verbal description of a visual artwork, and in the original sense of the bringing to presence of a scene in the imagination of an auditor, through force of language. ${ }^{4}$ It is a rhetorical exercise made freshly resonant now as description is reclaimed and re-valued in certain quarters as a significant register of contemporary writing. To speak in the broadest terms, the register imagined is essayistic and episodic, although circumscribed by some kind of holding tension; little concerned with the formalities of narrative; suggestive of an experiencing and writing first person, however discontinuous, conceptual or contested the personhood; tending to avow and affirm rather than explain or critique; and, regarding classification as creative or critical, decidedly open. Evidence of and advocacy for work in this vein can be found across a wide spectrum of contemporary writing: in the recent art criticism of T. J. Clark; in the essays of Wayne Koestenbaum and the poetry of Lisa Robertson; in Kathleen Stewart's experiments with improvised forms of descriptive ethnography; and in Timothy Morton's suggestion of a speculative-realist ekphrasis. Even the contemporary novel has been identified as having description and ekphrasis as two of its signature modes, in recent critical work by Timothy Bewes and David James. ${ }^{5}$

Journals', http://intercapillaryspace.blogspot.co.uk/2008/08/being-seen-for-seeingtribute-to-r-f.html (last accessed 14 August 2017).

${ }^{4}$ On the distinction between the modern and ancient conception of ekphrasis, see Ruth Webb, Ekphrasis, Imagination, and Persuasion in Ancient Rhetorical Theory and Practice (Farnham: Ashgate, 2009).

${ }^{5}$ T. J. Clark, The Sight of Death: An Experiment in Art Writing (New Haven and London: Yale University Press, 2006) and 'Poussin's Sacrament of Marriage: An Interpretation', New Literary History, 45.2 (2014), 221-52; Wayne Koestenbaum, Notes on Glaze: 18 Photographic Investigations (Brookyn, NY: Cabinet, 2016); Lisa Robertson, The Weather (London: Reality Street, 2001); Kathleen Stewart, Ordinary Affects (Durham and London: Duke University Press, 2007); Timothy Morton, Here Comes Everything: The Promise of Object-Oriented Ontology', Qui Parle, 19.2 (2011), 163-90 (pp. 170-71); Timothy Bewes, 'Introduction: Temporalizing the 
In the reading that follows here I take Langley's prose, still to be read in any detail, as offering something of a test case for description's new found contemporaneity - although not because the writing in question is in any way novel (and notwithstanding its age). Langley acknowledges an inheritance, working from within the register occupied rather than looking to overturn or drastically re-imagine. The attendant modesty, a kind of measuring of what is in view, is one integral aspect of the contemporaneity of the writing as we experience it now. In keeping with this measure, and with current interest in a closer alliance of critical and creative practice, my reading of the Journals is descriptively inclined, occupied with item and inventory. I focus closely on a series of small-scale inflections of description's discursive repertoire: beginning with a frame and moving thus through counting and measure, fancy, seething and leaking, and praise. The intention is to enumerate the rhythms and figures of Langley's prose; to show these as exemplary of what recent accounts of description have claimed for the mode: a singularly sympathetic thinking in writing, concerned as Macdonald says with 'mapping the processes of thought, the working out of things' ${ }^{6}$

\section{'Frame that'}

Description has long been conceived as a matter first of framing: the locating of an occasion, with the frame as the means of arriving on the scene. Langley alludes to frames intermittently through the days and nights of journal writing, in the material markings of art and architecture - the splays of a church window conjuring - a 'framed presentation' - and in performative and self-summoning injunctions to gather what is to hand and thereby make the scene: 'frame it now with Sunday morning' (p. 81; p. 56). Description as a 'constrained field[s] of action' begins thus in a scenario of

Present', Novel 45.2 (2012), 159-64 (p. 160); David James, 'Critical Solace', New Literary History, 47.4 (2016), 481-504. For an extended account of description as a form of contemporary writing, see Stephen Benson, "“What shall be our new ornaments?" Description's Orientations', Textual Practice (forthcoming).

${ }^{6}$ My reading is exclusively of the Journals. On the illumination of Langley's poetry by his prose, and vice versa, see Conor Carville, “The Degree of Power Exercised”: Recent Ekphrasis', in The Oxford Handbook of Contemporary British and Irish Poetry ed. by Peter Robinson (Oxford: Oxford University Press, 2013), pp. 286-302. 
arrival, moving from outside to in, then stopping. ${ }^{7}$ Such framing devices indicate the affiliations of Langley's set pieces with the rhetoric of ekphrasis (or descriptio); indeed, the Journals comprises a veritable catalogue of types, identifiable most easily by referent: from ekphrases on artworks to, inter alia, accounts of place (topographia), land (geographia), water (hydrographia) and action or event (pragmatagraphia). Hence the detailed and sometimes repeated annotation of a small number of scenes, whether located inside, in the decorated spaces of a medieval church or in the presence of individual paintings and sculptures; or outside, most often in the fields and woodland of north Suffolk, and on its shoreline, with mammal, bird or insect. Langley's prose, in its animating presentation of a scene's having been framed and found to matter, testifies to the rhetoric of description as both epideictic, concerned in this case to praise as well as to persuade and thereby implicate the auditor; and as a variety of enargia in which the evocative persuasions of descriptive writing are always and knowingly an effect of style.

These contemporary descriptions are thus in a tradition, including in the manner of their beginning. ${ }^{8}$ And yet as Philippe Hamon notes, 'The term "frame" [...] that often metaphorically designates description, within the larger general metaphor of ut pictura poesis, signifies [those] decorative and secondary functions that theory assigns to description' ${ }^{9}$ It is precisely this framing of description as auxiliary or ornamental that is at once both acknowledged and occupied creatively by the kinds of

${ }^{7}$ Langley uses this phrase of the misericords in Ripon Cathedral: 'constrained fields of action under the seats' (p. 107). This is one of a number of self-reflexive analogies with description involving in each case a material object. Here, the solid purpose of the seat carries, verso, a decorative supplement the viewing of which frustrates utility (seated or standing).

${ }^{8}$ Langley refers to the writing of the Journals as 'description' in the preface to the volume (p. 7).

${ }^{9}$ Philippe Hamon, 'Rhetorical Status of Description', trans. by Patricia Baudoin, Yale French Studies, 61 (1981), 1-26 (p. 16). The first chapter of Cynthia Sundberg Wall's The Prose of Things: Transformations of Description in the Eighteenth Century (Chicago and London: University of Chicago Press, 2006) provides a helpful overview of description's mixed fortunes ('A History of Description, a Foundling', pp. 7-40). 
descriptively inclined writing identified and theorized in recent years. The notion of a so-called 'descriptive turn', first proposed in the 1990s, originated in the social sciences and has spread thence across the disciplines and their objects, including most recently to literary criticism and literary history; has spread, that is, both to the descriptive practice of a discipline and to the objects of that discipline understood as being themselves descriptive. ${ }^{10}$ Description in this latest framing is not so much reconceived as rediscovered and transvalued, in the immediate context of a humanities community increasingly sceptical of the effects and efficacy of its own scepticism. The context is understood in relation primarily to the hermeneutics of suspicion that was the default critical mode in the 1980s and 1990s, a mode reliant in

10 The rise to prominence of description and its methods can be traced in two special issues of Representations. The first, from 2009 (108), considers 'The Way We Read Now'. 'Surface Reading' is the notion proposed in the editors' introduction, with description figuring prominently as an instance of one such post-symptomatic critical mode. By the time of the second special issue, in 2016 (135), description has been established as the defining topic. 'Description Across Disciplines' is the title of the issue, and 'Building a Better Description' the title of the introduction. The notes to the editors' introduction provide a valuably comprehensive scanning of description's presence contemporaneously across a range of humanities and social science disciplines. A full reading of the diagnosis on which the curative proposal of description is based, to say nothing of the cure itself, is beyond the remit of the present essay. Note, however, the continued influence as provocation of Eve Kosofsky Sedgwick's 2003 essay, 'Paranoid Reading and Reparative Reading; or You're So Paranoid You Probably Think This Essay is About You', an early version of parts of which appeared as long ago as 1993 (Touching Feeling: Affect, Pedagogy, Performativity (Durham and London: Duke University Press, 2003), pp. 123-51). See also Rita Felski, The Limits of Critique (Chicago, IL: University of Chicago Press, 2015); and Rónán McDonald, 'After Suspicion: Surface, Method, Value’, in The Values of Literary Studies: Critical Institutions, Scholarly Agendas ed. by Rónán McDonald (Cambridge: Cambridge University Press, 2015), pp. 235-48. David James links the descriptive tendencies evident in selected contemporary novels with the contemporaneous descriptive turn in critical practice, according to a shared notion of consolation ('Critical Solace', New Literary History, 47.4 (2016), 481-504). 
its workings on depth- and distance-oriented metaphors of revelation and exposure. Hermeneutics thus conceived is 'heroic', totalising and paranoid by inclination, and constitutionally immune to the imagined pliability of the non-specialist reader. In response to the dominance and perceived long-terms effects of this environment, a number of counter-practices of so-called 'post-critical' reading and writing have been proposed in recent years; and it is as part of this proposal that description has come into view as a register of contemporary writing. Specific elements of this critical turn are of particular interest for an account of Langley's prose: an acknowledgement of the plenitude of detail and its untotalisable tendency to stray, hence those claims made on behalf of the play of the surface; an attitude of susceptibility rather than of calculated resistance or subversion; and a concomitant transvaluing and sustaining of strategically or self-consciously 'modest', 'weak', 'sympathetic' or 'thin' registers of verbal response.

Two in particular of the recurring motifs of the historical discourse attendant on descriptive writing are recognisable in these elements: the attachment of description to the surface of things - that is, to the concept of the surface - so to the matter of accidentals as opposed to essentials (each so-called); and as corollary to this attachment, the disputed status of describing as it supports, frustrates or revises the twin demands of interpretation and narration, which disputation includes potentially the charge of quietism. As is no doubt apparent, description as I am framing it here, and as it has been discussed recently, is imagined, if not as a genre, then as a specific register of writing with an identifiably attentive orientation or inclination towards its objects, differently inflected across the ages but with a consistency of tone and ambience, not least as marked by the motif preoccupations of the attendant critical discourse. The proposal of a new-found contemporary resonance is in one sense evidence of the reflexive move whereby description's own methods, its forms of attention, are taken up and recycled in its discursive fixing. Contemporaneity has always been at stake in the discourse in relation to description's animation in the moment of its scenes and objects, as these are imaginatively visualised through the force of rhetoric. ${ }^{11}$ Hence that dilemma of time and timing whereby the very

\footnotetext{
${ }^{11}$ Hence classical ekphrasis: 'Mere words are credited with the ability to make absent things seem present to the spellbound listeners, to control the contents of the most intimate of faculties, the imagination' (Webb, Ekphrasis, p. 8).
} 
animation asked of describing is taken in its vivification to be dependant on an emptying out and so disavowal of history. It is an effect of temporal flattening or stilllifing, operative also, so sounds the sceptical note of the discourse, in the paratactic detailing that, rather than ordering, initiates a potentially interminable and valuedenying, even dangerous, cataloguing of parts. ${ }^{12}$ Langley gestures performatively towards these aspects of the mode in deictic invocations - 'Here it is'; 'I am here' ( $p$. 126; p. 128) - and, by association, in the sometimes self-conscious arrangement of 'this bit, then that' in the time of the prose. (p. 22) Again, the Journals is avowedly in the tradition, albeit inventively, hence the dual focus of the reading that follows.

It is in part the contested present-making to which Langley alludes when, having acknowledged journal writing as a practice of description, he admits that 'Some poetics might scorn such business, some philosophy might decide it is a futile enterprise' (p. 7). Langley's singular negotiation of description's several tendencies is of course enacted in the matter of the writing itself, in the essaying of each entry. Indeed, one motif in recent commentary has been a renewed acknowledgement of the verbal texture of descriptive prose, hence of the rhetoric of description as involving 'feats of writing'. ${ }^{13}$ To nominate a repertoire for a specific practice of descriptive

${ }^{12}$ On the one hand, description is limited in relying on the temporal successiveness of verbal discourse, while on the other, its denial of hierarchy and ordering spatialises historical time, making a still life of whatever it surveys. The debate is nearly as old as the mode itself. As Claire Preston notes with reference to Renaissance ekphrasis, 'The temporality of poetic description had long been presented as a deficiency of the verbal in the arguments of the paragonists' ('Ekphrasis: Painting in Words', in Renaissance Figures of Speech ed. by Sylvia Adamson, Gavin Alexander and Katrin Ettenhuber (Cambridge: Cambridge University Press, 2007), pp. 115-29 (p. 119)). The now classic modern statement of the case against description is György Lukács, 'Narrate or Describe?' (1936), Writer and Critic and Other Essays, trans. Arthur D. Kahn (New York: Merlin, 1978), pp. 110-48.

${ }^{13}$ Michael Fried, 'No Problem', Representations, 135 (Summer 2016), 140-49 (p. 146). Fried provides a roll call of art critics whose descriptive work is 'of writerly as well as “disciplinary” value', including T. J. Clark, Leo Steinberg and Stephen Bann. Clark in particular has taken an avowedly descriptive turn, beginning with The Sight of Death. 
writing such as Langley's is most obviously to mark a performance in the written work of something made by another, at another time, and now re-made. The Journals certainly works as such, occupying and performing a collection of the formal modes of the rhetorical exercise of ekphrasis. These modes are allied in Langley's version of description to related registers of more recent invention: of natural history, art criticism and psychoanalysis. Langley performs his chosen repertoire and in so doing, establishes one that others in turn might take up and enact (the sense of enablement felt by the reader is just one instance of the generosity of the writing). And yet repertoire is also repertory in the sense of something found, brought forth, and perhaps invented by chance, hence the not always harmonious responsibilities of musical or theatrical performance, both to the established text and to the reestablishments of each new enactment. It is in the interplay of these two meanings performance and invention, what we might identify now as the critical and the creative - that the peculiar traits of a repertoire can be identified, and with them the claims of the work on both reader and world.

It is a serious matter, this reading and writing, but also deeply pleasureable, notwithstanding that historically, as Hamon suggests, 'the pleasure of producing it [description] and the pleasure of consuming it' has been one of the 'blind spots' of the discourse. ${ }^{14}$ It is, then, more than merely tasteful to mark the singular pleasure of reading Langley, as prelude to the nomination of a repertoire proper; the concentrated pleasure, 'impromptu', of the repeated striking of a beginning. ${ }^{15}$ As Roland Barthes noted, journal writing's shirking of the responsibilities of extended development frees

\footnotetext{
${ }^{14}$ Hamon, 'Rhetorical Status', p. 25.

15 'Usually I would give myself a short time in the morning to write about the day before, if it seemed likely to be worth it, so the whole affair was necessarily impromptu' (p. 7). On the poetics of journals and diaries with reference specifically to British nature writing, see Mary Ellen Bellanca, Daybooks of Discovery: Nature Diaries in Britain, 1770-1870 (Charlottesville, VA: University of Virginia Press, 2007). Peter Riley's The Llŷn Writings (Exeter: Shearsman, 2007) is an interesting contemporaneous site-specific journal text to read alongside the Langley, albeit Riley mixes poetry and prose.
} 
and heightens by condensation the pleasure of tone and timbre. ${ }^{16}$ Langley's prose is largely unobstrusive - 'No more writing for gawps' (p. 125) - characterised by long paragraphs both precise in noticing and naming, and loose in their passage: between lines - 'Walking through sentences' (p. 22) - and between objects and incidents. The language is unshowy but has what Mcdonald calls a 'compressed and fierce' energy, a sense that something is being made to happen. ${ }^{17}$ The contained looseness, a kind of surface tension, allows for momentary diversions, contractions and expansions staccato; rubato; rallentando - resulting in a written field alert and animate: a 'vital atmosphere'. ${ }^{18}$

\section{'Life is bound to be framing and counting'}

The first item proper in the repertoire of Langley's descriptive prose, once the latter has been framed as such, is counting. It appears in an early set-piece ekphrasis, an artfully framed description of Nicholas Stone's 1627 tomb of Elizabeth Coke in the chancel of St Andrew's in Bramfield, Suffolk; specifically, in the substance of the monumental sculpture itself and, towards the close of the entry, the noting that 'Stone kept account books' (p. 17). Accounting in his turn, Langley pays descriptive attention to the material - alabaster - and to the effect on it of coloured light. The 'brilliant surface', in its undecorated parts, 'comes clear of everything you can say', necessitating a series of edible analogies to be made to stick in language - 'dried oranges $[\ldots]$ caramel [...] creamed coffee': 'The stone becomes a food'. Conversely,

\footnotetext{
${ }^{16}$ Roland Barthes by Roland Barthes (1975), trans. Richard Howard (London:
} Papermac, 1995), pp. 93-95. Both Barthes and Langley are resistant to the sense of an ending: 'he doesn't like the ends: the risk of the rhetorical clausule is too great: the fear of not being able to resist the last word' (Roland Barthes, p. 94); and 'One can always manage the falling cadence. A journal is a pile of such' (Langley, Journals, p. 25). Barthes was of his time in being an arch-enemy of description, albeit his prosecution restates elements of a long tradition of anti-descriptive rhetoric. ${ }^{17}$ Helen Mcdonald.

18 'Vital atmosphere' is a phrase used by Eve Kosofsky Sedgwick in a reading of description and relationality in Proust ('The Weather in Proust', The Weather in Proust (Durham and London: Duke University Press, 2012), pp. 1-41 (p. 15)). 
and in keeping with the formally ekphrastic register, description finds its foothold in the 'bold, packed patterns' of the decorated surface where it has been etched; that is to say, where the surface has been eaten away. These 'inroads' catch the eye. In being patterned they are countable, free of the need of figurative assistance. To be countable is to be available for descriptive inventory: 'You can count parts of the pattern of her lace. You can take such facts away with you easily'. Hence the noting and listing of 'wheels $[\ldots]$ bars and flower-suns $[\ldots]$ buckles $[\ldots]$ Pipped and seeded shapes $[\ldots]$ stars crookedly set'; all the details, passed seamlessly from inscription to description.

Etching is registered as 'order picked out', hence as a means of letting 'mathematics into the sculpture'. And with mathematics comes prose. Mathematics is 'something that the mind can cope with on its own terms', and cope 'easily', whereas the memorial's carved drapery, all smoothness, was 'cut while nobody counted anything', by 'hands and skill' the terms of which are not our own. Counting is thus double-edged: the noting and marking of what has mattered, but also, possibly, a tooeasy domestication, the describable as decorative detail: an ornament for the real substance, namely, in this instance, the smoothly allusive surface. The scenario of this set-piece voices a trope of scale long familiar from the discourse of description - from Lessing's Laocoön, most influentially - according to which the ostensibly spatial alloverness and simultaneity of perception is sacrificed in language to the prosaic onething-at-a-time required of syntax, making for detail, hence for decoration, rather than for overview and summary. Counting, on the one hand, is an act of knowing-asnaming: as Langley writes elsewhere, 'counting things is the purest way you've got of knowing things'; ${ }^{19}$ and naming, the naming of parts, is a means of accounting for what has been given, a modest act of calculation and settling up. It is the modesty of those field guides carried or consulted after the fact - 'I have the book in the binoculars' case' (p. 40) - guides whose nomenclature and functional descriptions identify and thereby confirm what has been and will be seen by others, in other places at other times. Inventorial confirmation allows a moment of benign coincidence in which 'Words come true' (p. 42). Rhetoric, in its conventional reliance on public

19 'R. F. Langley Interviewed by R. F. Walker', in Tim Allen and Andrew Duncan (eds), Don't Start Me Talking: Interviews with Contemporary Poets (Cambridge: Salt, 2006), pp. 237-57 (p. 249). Larkin identifies this aspect of the writing as evidence of a 'Romantic and post-Romantic particularism'. 
space and ritual performance, however virtually, is confirmed, along with an opensource vocabulary shared rather than privately owned: 'something to count on' (p. 79).

This on the one hand. On the other are those things that 'break up the accountable' and question countability itself (p. 76). To count is necessarily to countenance the possibility of recounting, from which implied secondariness follows a string of synonyms inflected pejoratively in the Journals as 'familiar codifications': 'fiction'; 'narrative'; 'story'; 'script'; 'role'. These, the mind can cope with all too easily. The ritual modesty of naming is both a guard against description's repertoire, in the sense now of going through the motions, and the very means by which such motions are set in train. The trope here, or the scenario as figured in the writing, has been identified by W. J. T. Mitchell as one of three archetypes of the ekphrastic encounter: in this case, the 'ekphrastic fear' that follows on a realisation of the losses incurred in the ostensibly unavoidable mis-translation of seen to said, fear of which requires a prior distinguishing of remits, realms and objects, both verbal and otherwise. ${ }^{20}$ Langley sounds the note repeatedly as an irritated injunction to himself to 'stop scripting' - making a verbal meal out of a smooth surface, for example - and as a melancholic acknowledgment of words as the always belated reminder that 'Reality is not possible' (p. 125, p. 21).

This is relatively conventional conceptual territory. The specifically Langleyan trait of the counting motif resides in the matter of how, over the course of the Journals, the modest worth that is acknowledged in the act of inventory, the fact of something's being said to be so, is framed as the result of a decision made as to what should be significant. The note is sounded repeatedly in an entry from 1991, with the prose turning to catch itself in the act of describing. The subject is Mannerism, beginning with the domestic recognition-as-revelation of Caravaggio's Supper at Emmaus and moving thence by mannerist sidestep to a self-reflexive declaration: 'Life is bound to be framing and counting' (p. 55). ${ }^{21}$ Life, that is, or so

\footnotetext{
${ }^{20}$ W. J. T. Mitchell, 'Ekphrasis and the Other', Picture Theory: Essays on Verbal and Visual Representations (Chicago, IL: Chicago University Press, 1995), 151-81 (pp. $154-55)$.

${ }^{21}$ I assume Langley is referring here to the first of Caravaggio's two paintings of this scene, in the National Gallery, London.
} 
we might infer, is bound to be the bounding of description, whether that should come to be felt as obligation or restriction; as reassuring certainty or as disclosure. The counting that matters here is of the kind undertaken by the disciples and innkeeper at Emmaus, who 'will have to decide what to count'. And what is a description if not the result, however provisional, of a decision about what should count, so about what is or has been at stake? A mannerist concatenation ensues. Wordsworth, being with us in the here and now of this description - 'in our situation', as are Caravaggio's witnesses - 'will need to know' whether the described smoke seen rising from the trees upstream from Tintern Abbey 'count[s] enough to be worth an exclamation mark'. Likewise the dimensions of the pool in 'The Thorn', where the mother's newborn child drowned: 'can you know what those dimensions count for?' The answer to each question, rather than being determined in advance, is still to be given. Description thus conceived is not a mis-translation, and certainly not blessing or a revelation. It is an essaying of words on the possibility of the perceived world; a modest playing of a public register of names whose risks are the self-checking element in what is, each time anew, a case of accountability: 'a list made to settle what was there' (p. 19).

\section{'Fantasy blooms'}

Counting is suggestive of an Apollonian disposition, one drawn to 'The delight of the inconspicuous, the exact' (p. 79). And yet restraint in Langley, in the performance of conventions of framing and naming, tends also otherwise, towards a kind of abandon, excess or indecorousness that holds its own pleasures: as he says, 'You know I love things when they're incredibly precise, and yet move off all over the place as well. The tighter the wider'. ${ }^{22}$ Sometimes, as it gathers itself and settles with the world, the prose opens out as if unconsciously, in what feels to be an organic expansion in sympathy with the possibility of the rhetorical practice of ekphrasis as a form of explicatio, an 'unfolding' in language. ${ }^{23}$ The restrained energy of the counting finds

\footnotetext{
22 'R. F. Langley Interviewed by R. F. Walker', p. 250.

${ }^{23}$ See Webb, Ekphrasis, pp. 74-75.
} 
through the force of its own animation that it has or has made room to stretch. ${ }^{24}$ To say as much is to invoke the idea of repertoire as qualified invention, along the lines specifically of the 'rhythmic invention' - the 'free invention' - about which Langley wonders when looking at the carved bench ends in the church of St Andrew in Tostock, Suffolk (pp. 52-53); or the short-lived inventions of concerted English viol music, as heard by chance on the car radio: 'the form broken free from the line of the song into interplays of fancy' (p. 64). Invention is identified here in an artisanal English tradition where it is in counterpoint always with settled and recognised customs of composition and craft.

This play of fancy happens most conspicuously with the 'live stuff' of the words themselves (p. 100). The basic unit, in line with the rhetorical figure of congeries, is the little heap of etymology- or usage-derived incantation: 'Cope. Cape. Cap. Hood. Cloak', as derived from the coping bricks on the wall of a railway bridge (p. 98); or, from the carving of misericords: 'Notch. Groove. Bulge. Bump. Bunch. Bag. Block. Burrow. Fold. Crease. Polish' (p. 106). A Ruskinian account of the surface of an autumnal stream and surrounding life - description at its surfaces again - yields embellishments as the 'garnished pudding' of the scene generates an analogously clogged mesh of word stuff (p. 10). Elsewhere, the set-piece record of a spring-time visit to view woodland orchids and bluebells finds Langley dutifully identifying, naming and noting; but a tension in description's script soon spills over. Orchids suggest Hamlet, which suggests in turn a run of folk etymologies via Geoffrey Grigson; thence via a series of rudely fecund moves to Hopkins on bluebells, and back to Grigson and a further ringing of the changes, including on the naturalist's proper name (p. 103). The body of description rifles pleasurably through its own matter, courting in the process, in the play of 'idiom and... material' (p. 106), a breach of the rhetorical proprieties of description: a 'general tumbling around what is proper' (p. 98). While such playfulness might appear modern in its unmasking of the referential illusion, multiplying and so foregrounding description's material text, a notion of textualist unmasking does little to catch this item of Langley's repertoire, not least because the latter's counterpoint, an ethics of counting the world in words, is

\footnotetext{
${ }^{24}$ On ekphrastic writing as having a 'split personality', caught between binary imperatives of plainness and floridity, see Grant F. Scott, 'The Rhetoric of Dilation: Ekphrasis and Ideology', Word \& Image, 7 (1991), 301-10 (p. 303).
} 
always close to hand. Verbal invention is here a performance of variety in the rhetorical sense; variety, that is, conceived after Mannersim as an element of style the overflowing energies of which are not necessarily amenable to unification. Description becomes its own ornament at these moments of amplification, generatively self-decorating, as if modelled after the hares described leaping up in the grounds of the Minster at South Elmham: 'Leaping is the essence of opening. "Open" and "up" are the same word. Intuition is a hare. It brings its transformations' (p. 118). The prose likewise is never more sentient than when fancifully marking the matter of its own artifice. Style is self-exhibiting, happily unencumbered by those charges of decadence and sophistry that sound in the more repressive tones of the historical discourse of ekphrasis when the potentially gratuitous admittance of verbal ornament comes up against the responsibilities of a utilitarian function. ${ }^{25}$

The densely embellished paragraph on orchids and bluebells includes its moment of meta-descriptive self-instruction: 'To get it true and at the same time find it astonishing' (p. 103). As with an earlier such moment - 'The delight of the inconspicuous, the exact' (p. 79) - Langley marks the rhetorical simultaneity of naming and invention as counterpointed items of repertoire. ${ }^{26}$ And it is the nouns that resonate: delight and astonishment; the magic of a 'magical precision' (p. 136). The fancy of invention as conjured in the prose appears not only in heapings of word matter, but also in signature perorations at a higher degree of organisation - at the level of the sentence rather than the word - performing now a kind of delighting improvisation. Description works at these moments to articulate a heightened appreciation or apprehension, the prose becoming its own occasion as its inventions stretch outward. Attending a duo concert at the church at Blythburgh, the ekphrasis risks Ruskinian purple passages; but with the close of the music comes a different order of response. 'Giving rein', as a description of one of the two musicians, provokes a memory of the immersive, insect-like sound of rain on a lime tree. This

\footnotetext{
${ }^{25}$ Again, Scott provides a particularly helpful account of description's 'split personality' (Scott, p. 303).

${ }^{26}$ There are echoes in Langley's counterpointed terms of the 'attentiveness and wonder' claimed by Merleau-Ponty (and before that, by Husserl) for phenomenology (Phenomenology of Perception (1945), trans. Colin Smith (London: Routledge, 2002), xiv).
} 
won't do - 'scrap all that' - hence a turn, via 'panes', to 'the amazed attention of the outside', then to the tapping sounds previously marked in response to the bow of the musician: 'Gut and fibre cry, heckle and rage, joyfully'. Back thence to the angels on the church's roof beams, and now up and out to 'vapour trails' and the 'atmospherics in the ears [...] up to the stars' (pp. 24-25). Langley is at his most mannerist at these moments of rhythmed invention: virtuosic, capricious, playfully turning the descriptive matter as it unfolds. And yet it is not quite the Mannerism of the textbooks, glossed by Langley himself as a 'fracturing of gesture and state of mind so that they don't simply correlate' (p. 54). ${ }^{27}$ There is no fracturing - it is, as with the Caravaggio, 'a consistently recorded world' - rather a concern to represent as if contrapuntally the 'different ways of understanding what is there'. The mannerism 'taking place inside the characters' in the painting's scene is a matter here of prose register, as, again, 'the form [is] broken free from the line of the song into interplays of fancy' (p. 64). Description occasions its own invention, a self-decorating object settled amongst those others it has framed and counted.

\section{'Seethe together'}

As a discrete text of contemporary writing, the Journals presents a quasiconceptualist series of small-scale noticings, entry by entry, of surface detail as much as the micro-eventfulness of insect and flower. Langley stays with those accidentals so-called, of the field guide and of the field of perception generally, the latter conceived after phenomenology as it aspires to a 'direct description of our experience as it is'. ${ }^{28}$ The founding presence-to-oneself that is perception as conceived by classical phenomenology appears here specifically in the motif of coincidence as an elimination of distance and delay, however fleeting. 'Sometimes', so we read, 'you coincide with yourself, and there is a feeling of contact and immediacy' (p. 89). Yet the confirmations of one-to-one correspondence, while intermittently in the air, are

\footnotetext{
${ }^{27}$ Langley's thumbnail sketch of Mannerism is broadly in line with that offered at greater length by John Shearman in his classic account of 'the stylish style', published in 1967 (Mannerism (Harmondsworth: Penguin, 1990), p. 19).

${ }^{28}$ Merleau-Ponty, Phenomenology, p. vii.
} 
another of those relatively conventional scenarios that sound only as a minor note in the text. The Langleyan trait of scale as an item in the descriptive repertoire is instead something more various and mobile than self-coincidence would suggest; more eccentric, as suggested in the Blythburgh entry with its ricochetting shifts of scale, raindrop to roof beam, inner ear to stars. This eccentricity of scale is evident in the most ordinary of places: on a 'cream painted wall' in the house of friends recently travelled overseas, as 'boiling shadows' of light through the window play elaborately across the room's surfaces. Local details duly counted - the warp in the glass; the lily in the earthenware pot; a family photograph - they become caught up in a hallucinatory scalic rush across distances, from 'outer space' to 'this immediacy' and from 'prehistory' to 'history'. Immediacy yields 'Coincide' - there is that possibility, however generic-sounding - but it is a being-together not of presence and confirmation but of 'seething'; specifically, the material 'seething' that comes via the shadows 'trapped in the square' of sunlight the animated noticing of which has provoked the description (framing thus serving its purpose). 'All other points of view, systems, seethe together and blink out in this present seething' (p. 116). A present that blinks and seethes is no momentary coinciding of self with perceiving self or perceived world, but again, something animate and mobile; a coincidence only in the sense of being chanceful. Description thus essayed stages scale as an eccentric drama of proximity and distance, a mannerist unsettling of the regulations of perspective. ${ }^{29}$

Each of the more extended set-piece encounters in the Journals frames a bricolage of both matter and mode, often figured self-reflexively, if modestly: by the likes of the two different waste bags, for example, in an entry prompted by a winter meeting with a drake scaup, one of which bags 'contains [...] another' within it (pp. 122-23). Hence the figure of the 'ensemble', a lightly held collection or gathering of seemingly ordinary items that serves as a description both of the form of the journal and of its constituent entries as what is called elsewhere a 'putting together of parts' (p. 93). One such part, akin to coincidence as an item in the descriptive repertoire, is an understanding of the writing itself as establishing a comforting fiction of proximity, so as belated in relation to perception. The provoking image is of the scaup

\footnotetext{
${ }^{29}$ These mannerist conjurings of perspective might also be read in relation to ecocritical theorizations of the planetary and the posthuman as, specifically, scenarios of scale.
} 
'holding its head high and slightly tilted'. Descriptive counting ensues, part of which involves marking with the motif word 'close' the fact of distance felt as 'absolute' even when the bird is physically nearby. The writing hovers nevertheless over the idea of a desired closeness, both literal and metaphorical; a sign that 'some heed has been taken' of whatever is at hand. But close yields 'clause', and so sentencing: the possibility that one might 'interfere[s] with the lack of closeness by writing about it'. Closeness is figured as an effect of writing itself, never more so than in the paradoxical bringing-close of distance:

You close in on the head of the scaup [...] But it loses the quality it had before it seemed possible to write about it, which was that it was not close, that it was not coming closer, that it was, all the time you were aware of it, coming away [...] And perhaps an experience 'comes off' only before it is possible to write about it [.] (p. 123)

To describe is to produce by rhetorical sleight of hand a 'fake sort of closeness'. 30 Hence those self-chastening synonyms that appear intermittently in the Journals, united in their fixing of writing as forever and belatedly in a melancholic relation to the event thereby marked. 'Reality is not possible, because immediately the noise is in the past, and one of a pair or more of fictions' (p. 21). ${ }^{31}$

Description's arrival in a sentenced future of its own making marks the passing of a present that is always already 'slipping away' (p. 123). As with those

\footnotetext{
${ }^{30}$ In identifying description as a form of fakery, Langley sounds one of those binarycoded notes characteristic of the discourse. Ekphrasis thus conceived is 'a trick of the rhetorician's trade' (Jean H. Hagstrum, The Sister Arts: The Tradition of Literary Pictorialism and English Poetry from Dryden to gray (Chicago, IL: University of Chicago Press, 1958), p. 29).

${ }^{31}$ A 1979 entry describing a field of rabbits develops motivically along lines very similar to those of the later encounter with the scaup (pp. 20-22). A somewhat different account of closeness and distance appears in the bravura ekphrasis on Bellini's altarpiece at San Giovanni Crisostomo, in which Langley tests out a reading of the image by Richard Wollheim at the end of the latter's Mellon Lectures, published as Painting as an Art (Princeton, NJ: Princeton University Press, 1987).
} 
elements of repertoire already listed, the temporal scenario, with attendant binaries, is customary - but only up to a point. Description's future as framed in this entry is also the time in which the provocation of the present might find itself answered otherwise: for '[w]hat is there here to discover?' (my emphasis). Description thus framed - the question is the frame - is closer to a happening than a wake; closer to the seething together and blinking-out of shadow play than the resignedly melancholy texts of presents just since passed. 'Seethe together', a phrase used twice in the Journals, may at first appear too agonistic an orientation to characterize the calm vitality that pervades the prose. Lyn Hejinian, working a similar seam, chooses 'oscillation' to characterize her own experiments with the register: description as the occupancy of 'simultaneous but different logics, oscillating inferentially between induction and deduction'. ${ }^{32}$ Oscillation and simultaneity are certainly comparable to a Langleyan mannerism; and yet 'seethe together', suggesting as it does coincidence as animate simultaneity and a shaking-up of scale, provides an appropriately forceful counterweight in Langley to a default melancholy of perception. It first appears in the description of a field with insects. The prose gathers creatures it has started by framing and counting - ant-lion, tiger beetle, spider and gull - but rather than testifying textually to their being always other and elsewhere, they are picked up in a moment of fancy prompted by the motif and resonance of 'keen', gathered from Adrian Stokes. And so 'they seethe together', the insects and animals described, along with those 'foreigners' introduced fancifully in response by the describer - dwarf and ghost spiders - 'All parts of the same wisdom, some of it recognised, most of it new'. It is all happening, 'all couth, all uncouth'. And where are they in relation to you? Not near or far, now or in the past, but 'Set out into fields of deep space'. Again, the scale is hallucinatory as the writing conjures a 'seething together' of 'simultaneous but different' knowings. Description becomes 'uncouth' in its mannerist animation, only 'partly kenned' (pp. 92-94). In answer to its own framing question - 'What is there here to discover?' - description thus advertises what it can make happen: 'The process is all discovery'.

There is a strongly Kleinian inflection to these encounters, along with the phenomenology. The note is sounded explicitly in an ekphrasis that forms part of this

\footnotetext{
${ }^{32}$ Lyn Hejinian, 'Strangeness' (1989), The Language of Inquiry (Berkeley, CA: University of California Press, 2000), pp. 135-60 (p. 139)).
} 
same entry, on a Picasso of 1910. Analytic Cubism appears compositionally to work out a psychoanalytic orientation:

It [the painting] provoked your involvement in the putting together of parts, what you have to do in the world of objects and of experiences, assembling them, to knit it up [...] The body itself, and its parts, are 'prime objects', basic for relationships which are the basis of every kind of subsequent relationship. (p. 93)

Part-work along these lines is a procedural touchstone for the Journals' gatherings. Seething, however, while clearly a figure implying parts and wholes, is in no sense straightforwardly relational. Langley hints instead at something more porous, akin to the leaking roof at St Andrew's in Westhall, Suffolk, through which water drips, sounding miraculously as an 'opening [of] the space of the church' (p. 35, p. 38). The prose resounds overflowingly throughout with analogous animate and animating taps and chinks: 'the tight, hard chipping of the robins', for example, 'opening out the space' of a wood in much the same way as the raindrops in the church (p. 45). Leaking hints at the discovery of secret information, but also touches etymologically on lack. As such, it is perhaps the true figurative counter to that lack suggested by the conventionally melancholic framing of the belatedness of word in relation to world, and to coincidence as an idealizing self-contact. Description's seethings, as a quasibody, are in Langley's prose affirmingly leaky, in their verbal stylings as much as in their play with ideas. And if leakiness should be thought one nonce repertoire term too many, compare Roland Barthes, specifically Barthes's espousal of a pluralised, dispersed and processual 'difference': 'what matters is not the discovery, in a reading of the world and of the self, of certain oppositions but of encroachments, overflows, leaks, skids, shifts, slips..., ${ }^{33}$ A mannerist leaking of orientations and inclinations is what comes to matter in description as practised by Langley, not a reified set of oppositions or parts and wholes.

\section{'Glories'}

${ }^{33}$ Roland Barthes by Roland Barthes, p. 69 (my emphasis; ellipsis in original). 
Langley's exercises as I am framing them here follow description's calm measure but with a concatenation of registers and scales that punctures rather than reinforces boundaries, whether stylistic, temporal, spatial or relational. Nowhere does this understated turning of measure happen more joyfully than in the counter-discursive suggestion that description might both record and enact 'sudden understandings', interruptively rather than gradually and in succession; not so much as revelation, in the sense of a secret disclosed, as a surprised glorying (p. 18). The possibility is suggested especially where the writing is at its most glorious: in the centrepiece group of five 'densely modelled' entries describing time spent in the lighted spaces of the church at Westhall, with its various material occupants. ${ }^{34}$ Langley's prose is more emphatically praiseful here in these spaces than it is elsewhere, and it is this note of praise that sounds as the final item in the descriptive repertoire. Indeed, praise, in all its resonance, counts perhaps as the keynote of the volume and of the Langleyan orientation, an acknowledgement of ekphrasis as one of the modes available to epideictic rhetoric.

'What it is, this evening, is this: glorious. Glories' (p. 60). The determining 'this' in question is the side aisle of Westhall church on an August night. Gloriousness is in the first instance entirely appropriate, being a matter of 'Aureoles split and stretched and quivered, quivering'. Seething is happening again, nimble like the $q u$ of the quiver. It is the 'golden behaviour' of the light in the same side aisle as that described five years later, and the same type of framed but leaking play of outside on inside encountered in the hallucinatory bedroom scene (p. 82). In each case, and with a site- and etymology-specific suggestion of ecstasy, 'The open opens in insideness'. ${ }^{35}$ The play of light produces a repeated note of delight and a gesture of deixis - 'delight in what has happened', what 'is happening'; 'now and now', 'here and here and here' (p. 81, p. 60). Description works to count the colours and shades, but the protean plenitude thereby registered, in being 'beyond all normal uses,

\footnotetext{
${ }^{34}$ Respectively, pp. 35-39, 60-62, 62-64, 69-71 and 81-82. 'Densely modelled' is the phrase borrowed from Nelson Goodman by Claire Preston to describe thickly descriptive ekphrases, in comparison with those shorter passages that rely heavily on a reader or auditor to supply details ('Ekphrasis', p. 117).

35 The phrase occurs in Langley's ekphrasis on the Bellini in San Giovanni Crisostomo (p. 130).
} 
messages, instructions', appears like the light to break the decorum of the set piece (p. 60). Space is made animate by a light that, in its description, becomes overflowingly liquid: from 'half melted notices' and 'pouring' to an 'upstream [that] wavers and turns'; 'a whole river, and the particularities of which it is made up' (p. 81). There is 'sense' in here, and in being here. It is the sense of enumeration and precision, but also of 'copiousness'; 'astoundingly full, undiminished' in the first of these two entries (p. 60), and in the second, 'an inexhaustible resource of excited, various availability, pulled up in an unstoppable inhalation' (p. 81). The scale of the things of description, rather than being elaborated according to established relations of perspective, is once again hallucinatory in its 'complex eventfulness', such that 'surface and depth co-exist'. The 'print[s]' of the light as it plays on the splays of the two windows is its own writing, discovered in the same-but-different displaying of description's catching of it. Each is '[F] ountained up and away out of the top of the framed presentation', as if, in the gathering energies of its glorying register, description has passed now 'beyond all normal uses' ${ }^{36}$ It has finally leaked out of itself.

The note of praise struck resoundingly in these centrepiece entries is heard intermittently through the writing as it finds itself variously charmed, astonished and delighted. ${ }^{37}$ Praise thus expressed is not unrelated to the leaping up noted earlier, a mark and marking of abundance, but the trait is specifically one of recognition and gratefulness for what is elsewhere said to be 'perfect to an astonishment, a gratitude' (79). Where sometimes Langley as describer notes this being perfect as a function of precise detail, and that it is 'a delight to stake your attention on its precision', the most

36 'The fountain is a textual emblem of ekphrasis, whose energy can revivify trite objects, and arouse jaded readers'. So writes Michel Beaujour, with specific reference to the ekphrastic fountains in Guillaume de Lorris's Romance of the Rose ('Paradoxes of Description', Yale French Studies, 61 (1981), 27-59 (p. 37)). See also Sedgwick, 'The Weather in Proust', which commences with a Proustian ekphrasis on a fountain. ${ }^{37}$ As Susan Stewart says of the Hebrew psalms, those ur-texts of praisefulness, 'what is surrendered in praise is sound' (The Poet's Freedom: A Notebook on Making (Chicago, IL: University of Chicago Press, 2011), p. 35). Langley's occupancy of this register of response resounds all the more emphatically in a 'noiseless' space where 'all [is] seen and nothing heard' (Journals, p. 81). 
forcefully praiseful register is reserved for those occasions, necessarily rare, when events suggest 'the fantasy of a further cohesion' (p. 138, p. 140). The phrase appears twice in the final entry in the volume, with reference to a painting of Capel Curig made by Robert Leman in 1852. The ekphrasis of the painting's own describing takes an unexpectedly self-reflexive turn in the penultimate paragraph, Langley having noticed how a repositioning of one of the rocks in the image would fill part of the space under an adjacent bridge. A 'proposition' follows, the parts of the description oscillating now with those of the painting: "All the solid chunks in the picture would build into a smooth, complete wall, and, that done, become the whole smooth face of the sheet of paper, held firmly in its broad white mask, here in the gallery' (p. 139). Thus a 'further cohesion', registered as quasi-erasing 'fantasy', against which the given of the image and of the view seen by Leman, each its own real, stand as necessary 'resistance'. ${ }^{38}$ The fantasy happened, so we assume, at the time of viewing, but it is discovered performatively here in the 'further cohesion' of description's own 'sheet of paper' - its own happening.

Again, Langley's proposition is of a piece with his concern throughout for the multiplying rather than finalising relation of part to whole, so to the discovery by assemblage of how things, including the thing that is description, are or might be knitted together and apprehended as such by a desirously invested describer. If the individual journal entries is each an essay in miniature, it is this work of knitting that they tend often to be essaying, and which the reader, equally desirous, feels in turn as being in process. The relation is played out twice in those entries describing the things that constitute the world - in the thing described and in its description - and three times in ekphrases on thingly artworks that are themselves mimetic. The praise-prose set pieces, together with the passingly sounded praiseful notes of delight and astonishment, suggest a 'further cohesion' that knits together the volume itself as a discrete and sustained endeavour of descriptive registering.

Praise, in keeping with the orientation of ekphrasis, is responsive (as well as seeking in its turn a response). As such, and according to Susan Stewart, it is ostensibly a sign of 'secondariness':

\footnotetext{
38 'There's got to be something to push against' ('R.F. Langley Interviewed', p. 244).
} 
Our making takes place and proceeds within nature's dispensation; with these resources already present to hand, we make things that are also forms, and the material world becomes a resource for and, inevitably, an impediment to, our form making, for we are part of nature and finite within its infinity. ${ }^{39}$

A non-melancholic acknowledgement of the primacy of 'the given or received world' is certainly an item in the Journals' repertoire, albeit leakingly and seethingly constituted $;{ }^{40}$ and yet it would be misleading to frame Langley's praiseful register as responsive to a world conceived as resource, a world the praising of which is bricolage-like in its re-purposing of what is, naturally, 'to hand'. ${ }^{41}$ Stewart traces a responsive and relational praising, 'tied to those phenomena that evoke it, but [...] destined to circulate and enter into a general economy of human values' - values resulting from the appraising that praise performs. This is helpful as much for its articulation of something inherent in praise's workings as for its sounding not quite right, conceptually and tonally, placed alongside Langley. Response and the relation thereby established are a preoccupation of the Journals as both a repeated essaying of description. The writing is re-descriptive, a trying again of territory already tried, as if in contribution to a communal project of attention coloured intermittently by a familiar dream of pristine noticing. Langley's essaying seeks through its repertoire what Peter Larkin calls 'a sufficient relation': sufficient in the sense, first, of a finding enough in words to make a place alongside what has been found in the world; and second, in the sense of a meeting with the matter of words a need felt in the objects attended. The former is tinged understandably with an anxiety of adequacy, but this is of a piece with the 'compassionate correlation' - another of Larkin's telling phrases that is at stake in the prose. Description's neediness is the correlate of the described's needfulness, each the other's object (its given), each the other's correlate, each apprised in the co-relation. The general economy of such is other than merely human in its valuing, at odds with a "subordination of the description to the "human" the

\footnotetext{
${ }^{39}$ Stewart, Poet's Freedom, p. 29.

${ }^{40}$ Ibid., p. 32.

${ }^{41}$ Stewart's 'infinity', however generic in echoing an ancient conception of sacred abundance, is nostalgic as sounded at a time of environmental crisis.
} 
ostensible necessity and rightness of which appear occasionally in the discourse as regulatory imperatives. ${ }^{42}$

The tendency towards a register marked in the present reading of the repertoire by gestures of framing and counting is matched by the fanciful and the praiseful - not that matching is quite what happens. Items leak and overflow, however paradoxically in being articulated with restraint. The 'compassionate correlation', as Larkin suggests, is 'participatory', involving describer, description and described. For Larkin, Langley's achievement in this regard is precisely to indicate and push at the limits of description itself, the latter conceived as 'second cousin' to 'universal frameworks of explanation'. The suggestion is thus of 'the suspension of any purely descriptive motif' in the registering of an elusive 'more-than' that 'could never be just another describable aspect of the world'; the possibility that 'words could be implicitly offered in some engagement [with the seen and felt world] out-distancing description'. The 'more-than' remains apophatically 'undisclosed', as does the register of a description out-distanced, each in keeping with the negative theological tenor of Larkin's reading. And yet, has there ever been a 'purely descriptive motif' or a time when description was not already caught up in the possibility of its own outdistancing? The excess that Larkin marks in Langley's writing, the gratuitous surfeit of its praise in particular, is conventional in being a matter of description's own framings, its repeated attending to remit and borders. How much is enough? How much would be too much? What deviating damage might be done or benefit accrued by too much amplification and too little progression? What if description were to become a thing unto itself and so embellishment take on a surrogate life of its own? What register of writing is appropriate and by what standard might propriety be regulated and judged? The Journals offers a series of animating elaborations of such questions, each entry anew, each time working out what kind of claim description might or should make on reader and world.

At the end of a characteristically questioning description of a field encounter in August 1979, Langley acknowledges his own default desire for 'the absolute

\footnotetext{
${ }^{42}$ Hamon, 'Rhetorical Status', p. 13. Hamon's conclusion is that the discursive regulation of description through the ages is symptomatic of a general anxiety: that description 'might be the place in the text where the generative power of language might show itself most clearly and as quite unmanageable' (p. 25).
} 
sighting', and that his remaining unfulfilled is 'just as well, since that sort of given solves everything, and at once takes away the process in which we live and find any sort of responsibility, over "seventy thousand fathoms of water"' (p. 22). The relational repertoire of Langleyan description is no given and no solution, requiring an occasion to make a start and, as such, being always a picking up again of what is already in train. Description in its inventively conventional mixed mode, a mode Langley re-animates serially and from within, is a form of articulated responsibility for 'the process in which we live'. ${ }^{43}$ The fathoms of water that end this particular entry are Kierkegaard's figuring of faith as the preservation through risk of belief: 'If I wish to stay in faith, I must take constant care to keep hold of the objective uncertainty, to be "on the 70,000 fathoms deep" but still have faith. ${ }^{44}$ Fidelity cannot be fathomed except as its own form of understanding, its own counting. ${ }^{45}$ Likewise the fathoming of description as performed in the Journals, each entry of which, in the prosaic playing of its repertoire, 'find $[\mathrm{s}][\ldots][\mathrm{a}]$ sort of responsibility' in finding itself 'simultaneously to be out on 70,000 fathoms of water and yet [...] joyful.'46

${ }^{43}$ Compare David James's theorizing of description in contemporary fiction as offering a form of consolation ('Critical Solace').

${ }^{44}$ Søren Kierkegaard, Concluding Unscientific Postscript to the 'Philosophical Crumbs' (1846), ed. and trans. by Alastair Hannay (Cambridge: Cambridge University Press, 2009), p. 172. The quotation marks indicate Kierkegaard's quoting of the words of one of his own pseudonyms, Frater Taciturnus.

${ }^{45}$ Kris Cohen's account of description as an 'iterative [and] exploratory' 'weak theory' is strikingly similar to the Langley of the Journals, and to the reading of them offered here. Ekphrasis, for Cohen, 'generates a vocabulary of experience or encounter. It builds slowly but always asymptomatically to its objects rather than presuming their coherence [...] Ekphrasis, as critical methodology, generates a present tense, a tense in its ongoingness' (Never Alone, Except for Now: Art, Networks, Populations (Durham and London: Duke University Press, 2017), pp. 7-8). ${ }^{46}$ Søren Kierkegaard, Stages on Life's Way: Studies by Various Persons (1845), ed. and trans. by Howard V. Hong and Edna V. Hong (Princeton, NJ: Princeton University Press, 1991), p. 477. 